\title{
Analysis of the Effect of Temperature Differences on Surface Hardness and FeB Diffusion Process on DIN 34CrNiMo6 Steel Material Through the Boriding Process
}

\section{Analisa Pengaruh Perbedaan Temperatur Terhadap Kekerasan Permukaan dan Proses Difusi FeB pada Material Baja DIN 34CrNiMo6 Melalui Proses Boriding}

\author{
Umen Rumendi ${ }^{1}$, Achmad Muhammad ${ }^{1}$, Damarendro Hutomo Putro ${ }^{1}$
}

\begin{abstract}
The availability of materials that meet production needs is sometimes not easy to obtain. Material properties must meet the standards are physical properties, including violence. One method is to increase the value of the surface hardness of the material by the boriding process. Boriding is a surface hardening process through the process of diffusion of the substrate, thereby causing the material hardness to increase. The results showed the temperature in the boriding process of DIN 34CrNiMo6 material was proven to affect the surface hardness of the material. The FeB diffusion process begins to form at temperatures of $850^{\circ} \mathrm{C}$ and $950^{\circ} \mathrm{C}$. The optimal temperature for the boriding process is at a temperature of $950^{\circ} \mathrm{C}$.
\end{abstract}

\section{Keywords}

boriding, boron, temperature, FeB, surface hardness

\begin{abstract}
Abstrak
Ketersediaan material yang memenuhi kebutuhan produksi terkadang tidak mudah untuk didapatkan. Sifat material harus memenuhi standar adalah sifat fisik material, diantaranya adalah kekerasan. Salah satu metode untuk meningkatkan nilai kekerasan permukaan material dengan proses boriding. Boriding merupakan suatu proses surface hardening melalui proses difusi terhadap substrat sehingga menyebabkan nilai kekerasan material tersebut mengalami kenaikan. Hasil penelitian menunjukkan temperatur pada proses boriding terhadap material DIN 34CrNiMo6 terbukti dapat mempengaruhi kekerasan permukaan material. Proses difusi $\mathrm{FeB}$ mulai terbentuk pada temperatur $850^{\circ} \mathrm{C}$ dan $950^{\circ} \mathrm{C}$. Temperatur optimal untuk proses boriding adalah pada temperatur $950^{\circ} \mathrm{C}$
\end{abstract}

Kata Kunci

Boriding, boron, temperature, FeB, kekerasan permukaan

${ }_{1}^{1}$ Politeknik Manufaktur Bandung

Jl. Kanayakan No.21, Dago, Kecamatan Coblong, Kota Bandung, Jawa Barat 40135, Indonesia

*amuhammad@polman-bandung.ac.id

Submitted : May 11, 2020. Accepted : May 25, 2020. Published : September 01, 2020. 


\section{PENDAHULUAN}

Seiring perkembangan teknologi yang semakin pesat, dibutuhkanlah komponen yang mendukung proses produksi manufaktur, seperti halnya penyediaan logam. Disadari atau tidak unsur logam ini sangatlah penting dalam proses pengembangan teknologi bahkan hampir merambah semua aspek kehidupan manusia. Ketersediaan material yang memenuhi kebutuhan produksi terkadang tidak mudah untuk didapatkan. Material yang dimaksud seharusnya memiliki sifat material yang memenuhi standar yang ditentukan, salah satu sifat yang seharusnya memenuhi standar adalah sifat fisik material, diantaranya adalah kekerasan. Pengerasan permukaan adalah sebuah metode yang digunakan untuk memperbaiki sifat material namun hanya pada permukaannya saja sehingga pada bagian dalam material tetap memiliki sifat yang sama seperti sebelumnya. Kombinasi permukaan keras dan resistensi terhadap kerusakan berguna dalam bagian-bagian seperti roda gigi, bantalan atau poros, aplikasi turbin, dan komponen otomotif yang harus memiliki permukaan yang sangat keras untuk menahan keausan selama operasi [3].

Pemilihan material DIN 34CrNiMo6 didasarkan pada kemudahan untuk mendapatkan bahan tersebut serta seringkali material ini digunakan pada proses pembuatan suatu komponen penerus transmisi [10]. Di satu sisi, material tersebut masih memiliki kekurangan dalam kekerasan permukaan serta abrasi yang relatif rendah [8]. Salah satu metode untuk meningkatkan nilai kekerasan permukaan material dapat dilakukan dengan proses boriding.

Media yang digunakan pada proses ini adalah boron. Boriding merupakan suatu proses surface hardening melalui proses difusi terhadap substrat sehingga menyebabkan nilai kekerasan material tersebut mengalami kenaikan. Sedangkan proses difusi adalah proses merembesnya atom boron (B) yang berikatan dengan baja ( $\mathrm{Fe}$ ) menjadi FeB dengan kedalaman tertentu dan ditentukan oleh temperatur proses.

Pada penelitian ini, material DIN 34CrNiMo6 melalui proses boriding dengan menggunakan media boron bertujuan untuk mendapatkan material yang memiliki kekerasan permukaan yang tinggi. Perbedaan dengan penelitian-penelitian sebelumnya adalah proses boriding pada penelitian ini dilakukan dengan beberapa variasi temperatur tertentu dengan waktu holding time yang sama yaitu selama 1 jam.

Agar tercapainya tujuan dan manfaat dari penelitian ini, dibuat ruang lingkup untuk membatasi pembahasan masalah, yaitu penelitian ini hanya akan membahas mengenai analisa hasil perlakuan panas pada material DIN 34CrNiMo6 melalui proses boriding dengan beberapa variasi temperatur dan penelitian dilakukan di laboratorium heat treatment Polman Bandung.

\section{METODE PENELITIAN}

\section{Diagram Alir Penelitian}

Penelitian dimulai dengan mempelajari literatur yang mendukung dalam pelaksanaan penelitian. Proses selanjutnya persiapan spesimen untuk pengujian, persiapan peralatan dan fasilitas untuk membuat spesimen uji. Berikutnya proses permesinan dapat dilakukan untuk dengan dimensi $20 \times 12 \times 9 \mathrm{~mm}$.

Setelah spesimen uji disiapkan tahapan selanjutnya adalah melakukan proses karakterisasi awal seperti uji kekerasan awal, dan uji mikrostruktur untuk mendapat data awal spesimen uji. Setelah karakterisasi awal, proses boriding dilakukan, variabel pembeda tiap spesimen adalah tingginya temperatur. Variasi temperatur boriding yang dipilih adalah $550^{\circ} \mathrm{C}, 650^{\circ} \mathrm{C}, 850^{\circ} \mathrm{C}$ dan $950^{\circ} \mathrm{C}$ dengan waktu proses yang tetap selama 1 jam. Berikutnya adalah melakukan pengujian kekerasan dan uji mikrostruktur. 
Setelah semua pengujian dilakukan, maka didapatkan data kekerasan, data mikrostruktur lapisan yang terbentuk dan data proses difusi Boron terhadap Fe. Dari data-data tersebut kemudian dianalisa tentang pengaruh perbedaan besaran temperatur terhadap karakter spesimen uji boriding berdasarkan data-data yang didapat. Proses analisa dan pengolahan data dilakukan setelah semua proses pengujian dilakukan.

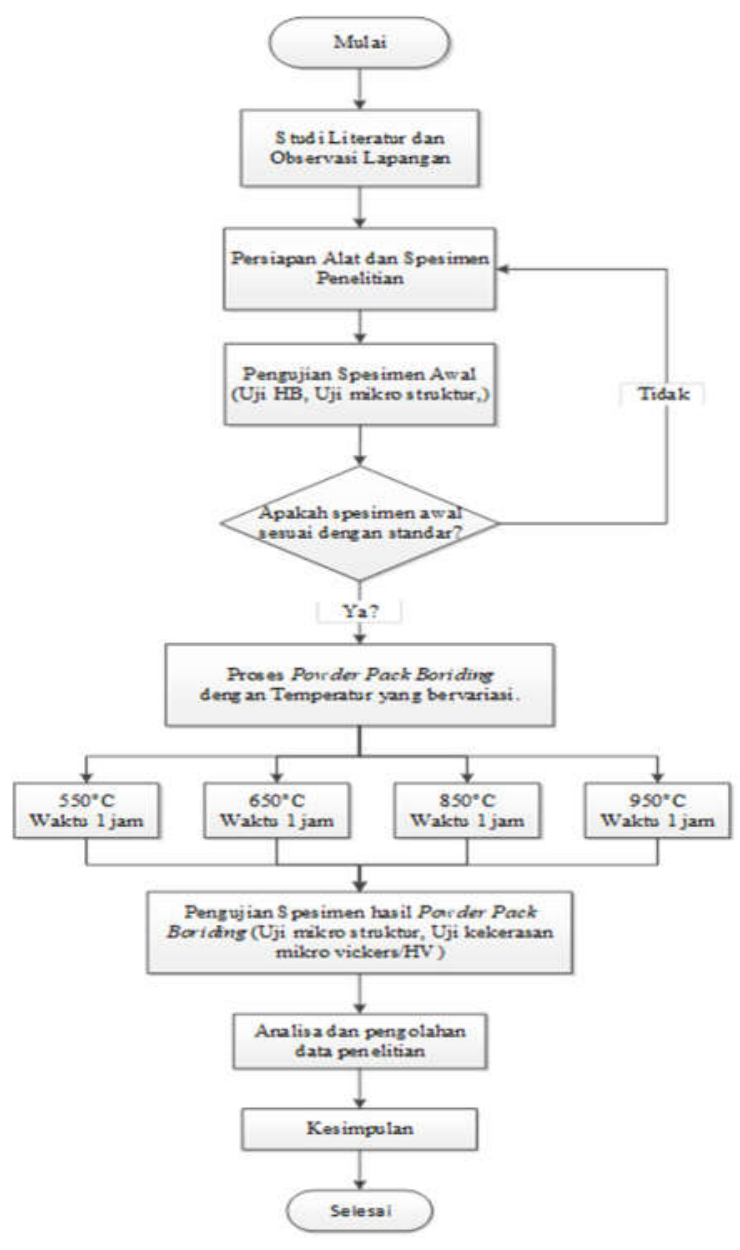

Gambar 1. Diagram Alir Penelitian

\section{Persiapan Alat dan Spesimen Pengujian}

Pada tahap ini persiapan alat dan spesimen pengujian dimulai dengan pipa St37 dan pupuk borate 48 dalam bentuk powder, kemudian memotong pipa tersebut dengan dimensi 2 inch $\mathrm{x}$ $250 \mathrm{~mm}$ sebanyak empat buah (Gambar 2). Siapkan pula media boron yang akan digunakan, pada penelitian ini digunakan pupuk borate 48 (lihat Gambar 3).

Setelah pipa selesai dipotong, langkah berikutnya adalah mengambil material DIN 34CrNiMo6. Kemudia masuk ke tahap permesinan dengan menggunakan mesin bubut untuk memperoleh dimensi $20 \mathrm{~mm}$ x $12 \mathrm{~mm}$ x $9 \mathrm{~mm}$ sebanyak 4 buah (Gambar 4) 


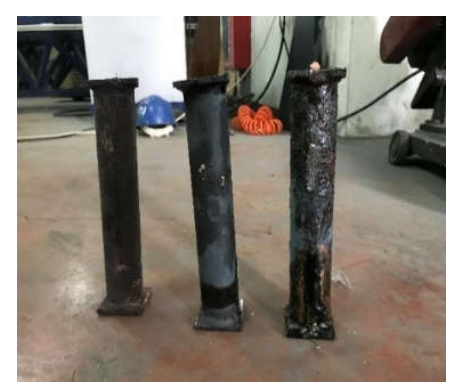

Gambar 2. Pipa St37

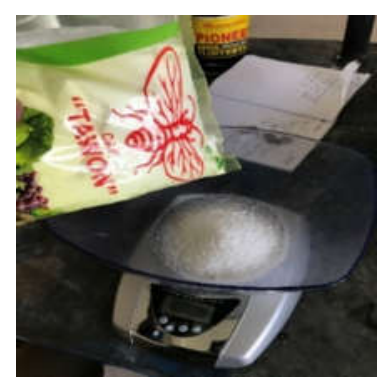

Gambar 3. Pupuk Borate 48

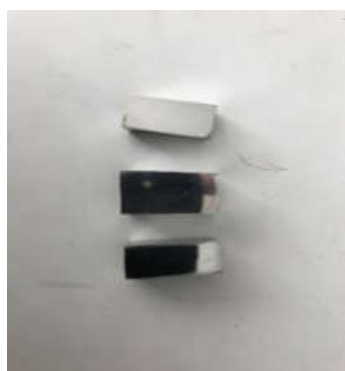

Gambar 4. Spesimen Uji

\section{Proses Boriding}

\section{Persiapan Media Boriding}

Pada penelitian ini, powder boriding menggunakan pupuk borate 48 dengan kandungan Boron sebesar $45 \%$ sebagai sumber boron, kalium 2\%, nitrogen $0.5 \%$, serta kandungan lain yang tidak tercantum pada kemasan. Pupuk tersebut dipilih karena dianggap lebih murah dan mudah untuk ditemukan di pasaran. Tidak dilakukan proses pemisahan unsur boron dikarenakan keterbasan fasilitas untuk pemisahan unsur. Konsekuensi dari hal tersebut mengakibatkan adanya kemungkinan terjadinya proses perlakuan panas yang lain seperti nitriding. Namun diharapkan dengan kandungan boron yang lebih tinggi maka proses yang terjadi adalah boriding.

Adapun rumus derajat ketersediaan atau degree of availability boron untuk mendapatkan berat boron dalam satuan gram. Dengan mengetahui luas permukaan spesimen yang akan diboronisasi maka berat boron dapat ditentukan dengan menggunakan rumus derajat ketersediaan boron, sebagai berikut:

$$
\text { Derajat Ketersediaan }=\frac{\text { Berat Boron }(\text { gram })}{\text { Luas Permukaan Boronisasi }\left(\mathrm{mm}^{2}\right)}
$$

Luas spesimen yang diboronisasi: $2(12 \times 9)+2(12 \times 20)+2(20 \times 9)=1056 \mathrm{~mm}^{2}$. Berdasarkan persamaan di atas, untuk derajat boron 0.15 maka berat boron adalah 158,4 gram, sedangkan untuk derajat boron 0.2 maka berat boron adalah 211,2 gram.

\section{Persiapan Tabung Pengujian}

Tabung reaktor pada penelitian ini merupakan pipa ST 37 dengan dimensi $\emptyset 2$ inci x 250 mm sebanyak 4 buah (lihat Gambar 5). Pada permukaan tabung bagian dalam dilapisi dengan flintkote yang dicampur dengan semen tahan api agar boron tidak terdifusi ke permukaan tabung.

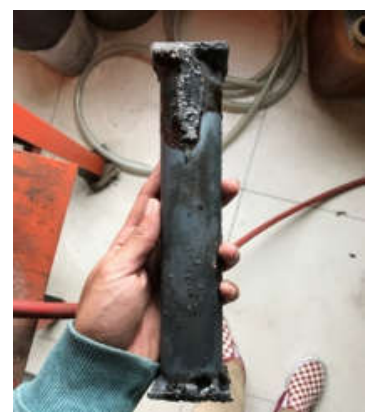

Gambar 5. Tabung Proses Boriding 


\section{Pengujian Karakterisasi Awal Uji Mikrostruktur}

Uji mikrostruktur dilakukan untuk memeriksa mikrostruktur yang dimiliki oleh sebuah material. Hal ini bertujuan untuk dapat membedakan hasil uji sebelum dan sesudah perlakuan heat treatment, Pengujian dilakukan dengan mikroskop optik (Gambar 3.6) yang memiliki skala pembesaran dari 100x, 400x, 1000x, dan 2000x.

Tahapan pengujian mikrostruktur dimulai dari persiapan spesimen uji, mounting spesimen, lalu polishing bertahap menggunakan amplas 180, 280, 400, 800, 1000, 1200 dan 1500, setelah itu melakukan etching dengan etsa nital 3\%, cleaning dengan menggunakan air yang mengalir dan dikeringkan menggunakan tisu.

\section{Uji Kekerasan}

Uji kekerasan yang dilakukan adalah uji kekerasan brinnel dan uji micro vickers. Kedua pengujian ini menggunakan mesin uji Micro Vickers dan Hard Brinnel (HB) (Gambar 3.7 dan Gambar 3.8). Uji kekerasan brinnel dilakukan untuk mengetahui kekerasan spesimen awal dengan $\mathrm{P}$ sebesar $250 \mathrm{~N}$, sedangkan uji micro vickers dilakukan untuk menguji kekerasan spesimen setelah diproses boriding. Uji micro vickers dilakukan dengan menggunakan beban 50 gram untuk mengetahui distribusi kekerasan pada spesimen yang sudah diproses dan juga untuk mengetahui kedalaman difusi boriding yang dilakukan dengan cara memotong benda kerja melintang dan mengukur kekerasan dari sisi terluar hingga sisi terdalam spesimen uji.

\section{HASIL DAN PEMBAHASAN}

\section{Hasil Pengujian Spesimen Awal Hasil Uji Kekerasan Spesimen Awal}

Uji Kekerasan yang dilakukan pada spesimen awal adalah uji kekerasan brinnel. Pengujian ini dilakukan pada spesimen DIN 34CrNiMo6 yang belum melalui proses perlakuan panas apapun pada beberapa titik yang berbeda (Gambar 6).

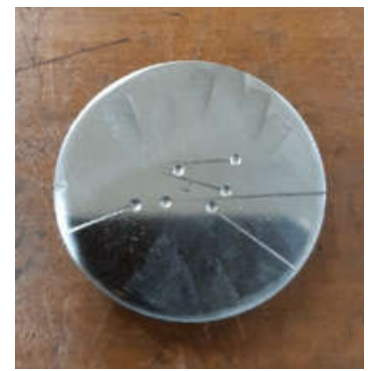

Gambar 6. Uji kekerasan brinnel

Berikut adalah data uji kekerasan HB (lihat Tabel 1).

Tabel 1. Data uji kekerasan brinnel

\begin{tabular}{|c|c|c|c|c|c|}
\hline \multicolumn{6}{|c|}{ Uji Kekerasan Brinnel } \\
\hline No. & d (mm) & D (mm) & $\mathbf{P}$ & HB & Rumus HB \\
\hline 1 & 1,25 & \multirow{6}{*}{5} & \multirow{6}{*}{250} & 364.82 & \multirow{6}{*}{$H B=\frac{P}{\frac{\pi}{2} D\left(D-\sqrt{D^{2}-d^{2}}\right.}$} \\
\hline 2 & 1,3 & & & 349.49 & \\
\hline 3 & 1,21 & & & 342.18 & \\
\hline 4 & 1,2 & & & 328.22 & \\
\hline 5 & 1,24 & & & 349.49 & \\
\hline d & 1,242 & & & 346,84 & \\
\hline
\end{tabular}


Data hasil pengujian kekerasan diperoleh nilai kekerasan material DIN 34CrNiMo6 memiliki rata-rata kekerasan sebesar 346,84 HB.

Tabel 2. Data uji kekerasan $H V$

\begin{tabular}{|c|c|c|c|}
\hline \multicolumn{4}{|c|}{ Uji Kekerasan Vickers Spesimen Awal } \\
\hline No. & D1 $(\mu \mathrm{m})$ & $\mathrm{D} 2(\mu \mathrm{m})$ & HV \\
\hline 1 & 31,87 & 31,59 & 328,9 \\
\hline 2 & 39,33 & 41,45 & 326,8 \\
\hline 3 & 37,17 & 38,9 & $\mathbf{3 2 4 , 5}$ \\
\hline 4 & 43,37 & 44,5 & 328,1 \\
\hline 5 & 49,55 & 49,2 & 322,3 \\
\hline \multicolumn{3}{|c|}{ RATA - RATA } & 326,12 \\
\hline
\end{tabular}

Data hasil pengujian kekerasan (lihat Tabel 2) diperoleh nilai kekerasan material DIN 34CrNiMo6 memiliki rata-rata kekerasan sebesar 326,12 dengan berat beban pengujian sebesar 200 gram.

\section{Hasil Uji Mikro Struktur Spesimen Awal}

Uji mikro struktur dilakukan untuk mengetahui struktur awal material dan memastikan bahwa material yang dipakai adalah DIN 34CrNiMo6, berikut hasil mikro struktur awal:

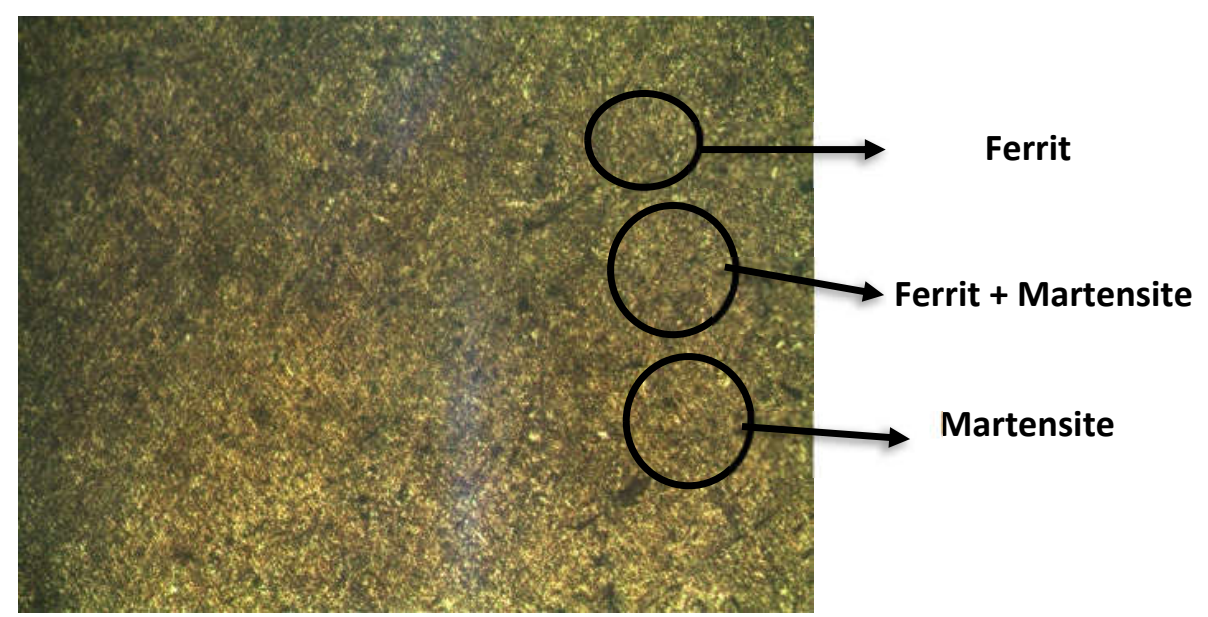

Gambar 7. Mikro Struktur DIN 34CrNiMo6

Gambar 7 adalah hasil uji mikro struktur spesimen awal DIN 34CrNiMo6 menggunakan perbesaran 400x menunjukan adanya ferrite $(\propto)$ dan struktur martensite, karena material ini merupakan material Pre-Harden yang mengakibatkan terbentuknya struktur martensite. Karakteristik fasa ini menghasilkan sifat keras dan termasuk $\propto+$ Martensite.

\section{Hasil Pengujian Spesimen Setelah Proses Boriding.}

Pada pengujian kali ini, terdapat empat spesimen yang akan diproses melalui proses boriding dengan variasi variabel seperti dapat dilihat pada Tabel 3 . Variabel bebas yang digunakan pada penelitian ini adalah temperatur, yaitu $550^{\circ} \mathrm{C}, 650^{\circ} \mathrm{C}, 850^{\circ} \mathrm{C}$, dan $950^{\circ} \mathrm{C}$. Sedangkan variabel tetap yang digunakan adalah waktu (holding time) selama 1 jam.

Tabel 3. Variasi variable temperature dan waktu

\begin{tabular}{ccc}
\hline No. & Temperatur & Waktu \\
\hline 1 & $550^{\circ} \mathrm{C}$ & 1 jam \\
\hline 2 & $650^{\circ} \mathrm{C}$ & 1 jam \\
\hline 3 & $850^{\circ} \mathrm{C}$ & 1 jam \\
\hline 4 & $950^{\circ} \mathrm{C}$ & 1 jam \\
\hline
\end{tabular}




\section{Hasil Uji Kekerasan Mikro Vickers Spesimen}

Pengujian ini dilakukan pada empat buah spesimen DIN 34CrNiMo6 melalui proses boriding. Pengujian dilakukan dengan dua cara, yaitu :

1. Pengujian dilakukan pada spesimen yang telah dipotong dan di mounting terlebih dahulu. Setelah itu diukur secara melintang dengan 10 titik pengujian yang berbeda, dengan berat pengujian sebesar 50 gram. Hasil pengujian ini akan menghasilkan grafik distribusi kekerasan Vickers.

2. Pengujian dilakukan dengan menguji secara langsung pada permukaan spesimen atau tepat pada perbatasan lapisan di lima titik berbeda dengan beban pengujian sebesar $50 \mathrm{gram}$.

\section{Hasil Uji Mikro Vickers Spesimen Boriding $550^{\circ} \mathrm{C}$}

Pada hasil pengujian distribusi kekerasan dengan beban 50 gram didapatkan data kekerasan permukaan luar spesimen sebesar 391,2 HV (lihat Gambar 7). Kekerasan dalam spesimen awal memiliki nilai yang cukup konstan dengan rata-rata 363,46 HV. Sedangkan pada hasil pengujian kekerasan permukaan nilai HV yang didapatkan paling besar berada pada titik ke 2, yaitu 396,8 dan memiliki rata-rata HV sebesar 370 HV (lihat Tabel 4). Hasil ini memperlihatkan nilai kekerasan dari sampel uji yang telah mengalami kenaikan kekerasan dari 327 HV menjadi $370 \mathrm{HV}$.

Tabel 4. Data Uji Kekerasan Permukaan Spesimen $550^{\circ} \mathrm{C}$

Spesimen $550^{\circ} \mathrm{C}$

\begin{tabular}{cccc}
\hline No. & D1 $(\mu \mathrm{m})$ & $\mathrm{D} 2(\mu \mathrm{m})$ & $\mathrm{HV}$ \\
\hline 1 & 24,89 & 25,88 & 363,5 \\
\hline 2 & 25,91 & 28,23 & 396,8 \\
\hline 3 & 23,33 & 26,30 & 357,1 \\
\hline 4 & 25,23 & 26,23 & 361,9 \\
\hline 5 & 26,14 & 25,28 & 371,2 \\
\hline
\end{tabular}

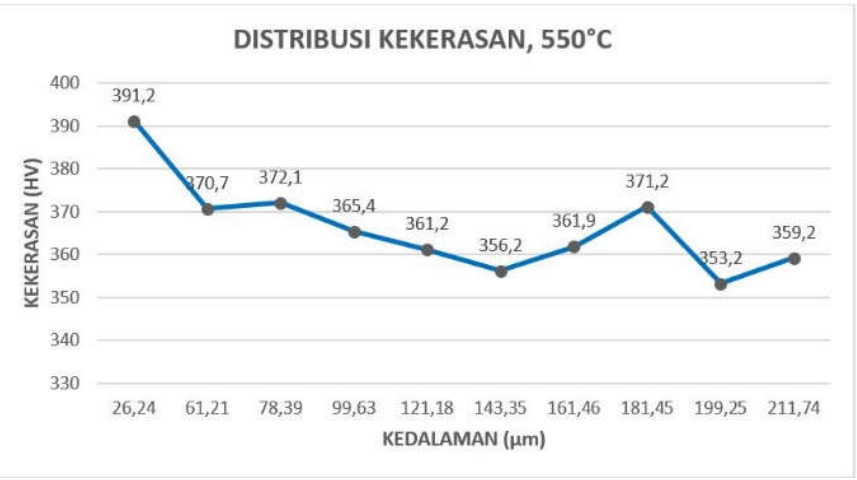

Gambar 8. Grafik Distribusi Kekerasan Spesimen $550^{\circ} \mathrm{C}$

Hasil pengujian mikro struktur hasil proses boriding pada temperatur $550^{\circ} \mathrm{C}$ menunjukkan pengujian mikro struktur pada tahap ini dilakukan untuk mengidentifikasi lapisan boron yang terbentuk serta melihat difusi yang terjadi antara Fe dengan B. Proses boronisasi pada temperatur $550^{\circ} \mathrm{C}$ terjadi penutupan permukaan seperti terlihat pada Gambar 8 senyawa borida yang masuk ke dalam substrat sangat sedikit. Fenomena ini dapat dimengerti dari mekanisme proses boronisasi. Proses boronisasi melibatkan difusi dan absorbs atom boron oleh kisi substrat yang menghasilkan senyawa boride (Fe-B). Terlihat pada Gambar 9 pembentukan reaksi Fe-B belum mampu untuk terdifusi ke dalam substrat. 


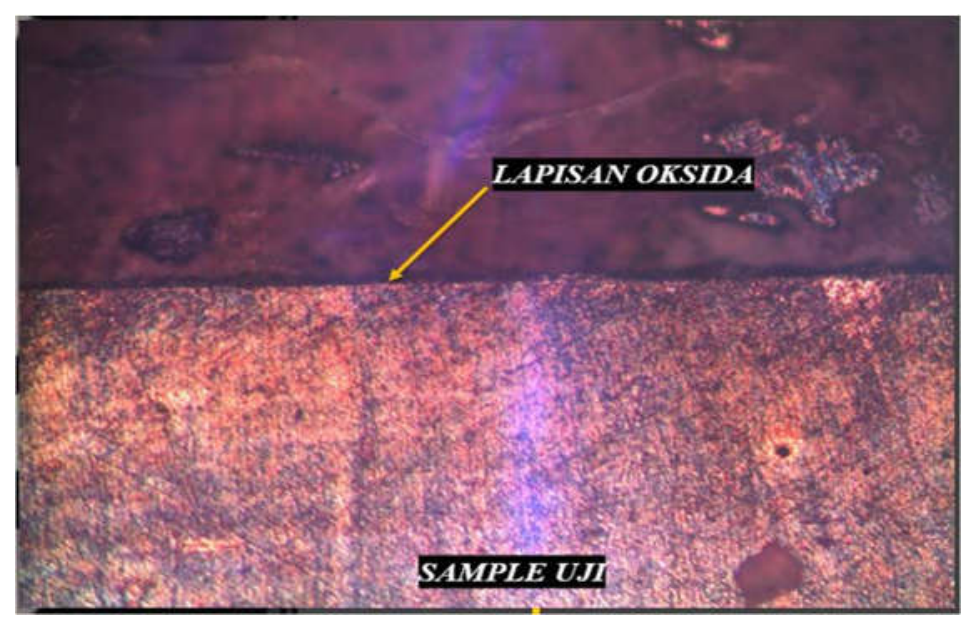

Gambar 9. Hasil Mikrostruktur Spesimen $550^{\circ} \mathrm{C}$

\section{Hasil Uji Mikro Vickers Spesimen Boriding $650^{\circ} \mathrm{C}$}

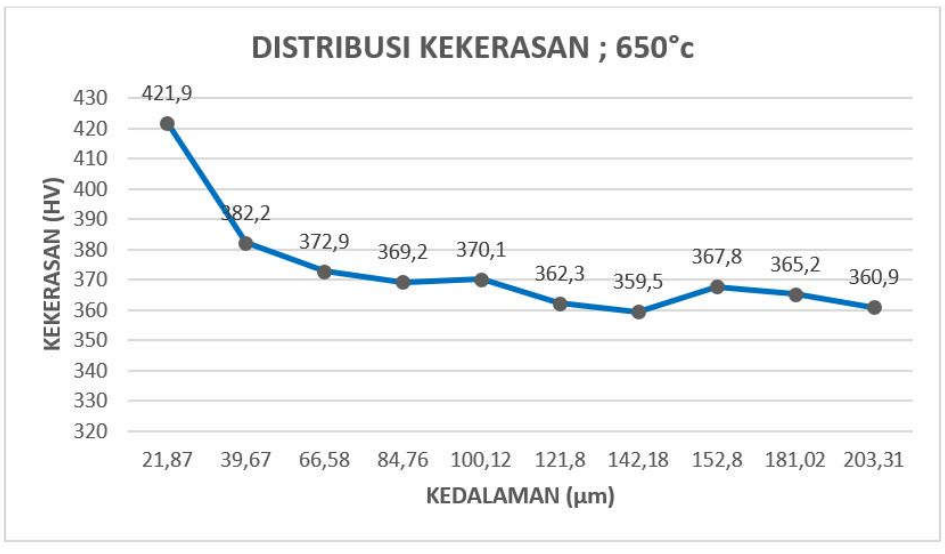

Gambar 10. Grafik Distribusi Kekerasan Spesimen $650^{\circ} \mathrm{C}$

Pada hasil pengujian distribusi kekerasan dengan beban 50 gram didapatkan data kekerasan permukaan luar spesimen sebesar 421,9 HV (lihat Gambar 10).

Tabel 5. Data Uji Kekerasan Permukaan Spesimen $650^{\circ} \mathrm{C}$

\begin{tabular}{|c|c|c|c|}
\hline \multicolumn{4}{|c|}{ Spesimen $650^{\circ} \mathrm{C}$} \\
\hline No. & $\mathrm{D} 1(\mu \mathrm{m})$ & $\mathrm{D} 2(\mu \mathrm{m})$ & HV \\
\hline 1 & 26,87 & 30,64 & 428,3 \\
\hline 2 & 26,14 & 30,58 & 409,5 \\
\hline 3 & 27,12 & 29,39 & 390,1 \\
\hline 4 & 27,70 & 30,35 & 381,6 \\
\hline 5 & 27,09 & 27,04 & 372,1 \\
\hline \multicolumn{3}{|c|}{ RATA - RATA } & 396,32 \\
\hline
\end{tabular}

Kekerasan dalam spesimen memiliki nilai yang cukup konstan dengan rata-rata 367,79 HV. Sedangkan pada hasil pengujian kekerasan permukaan nilai HV yang didapatkan paling besar berada pada titik ke 1, yaitu 428,3 HV dan memiliki rata-rata HV sebesar 396,32 (lihat Tabel 5). 


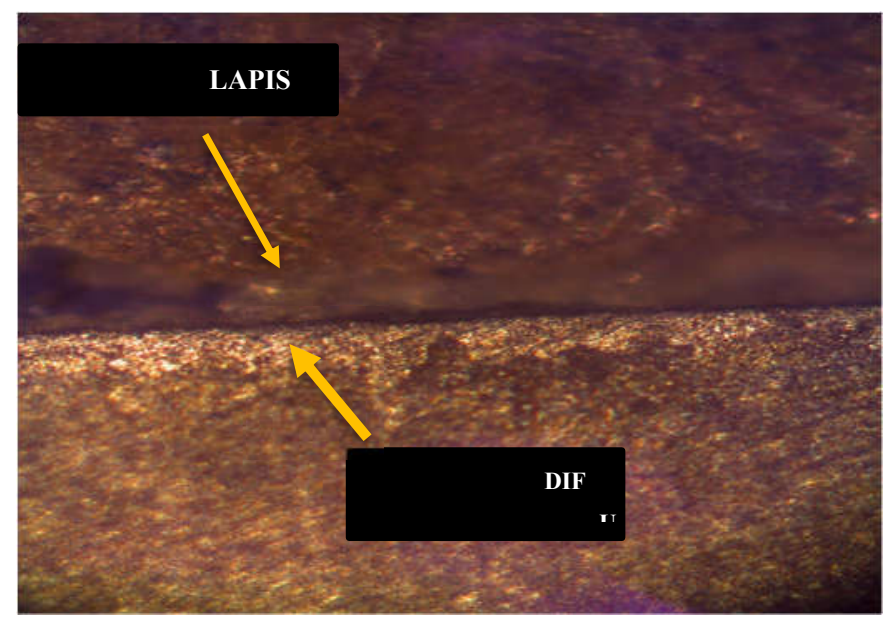

Gambar 11. Hasil Mikrostruktur Spesimen $650^{\circ} \mathrm{C}$

Proses boronisasi pada temperatur $650^{\circ} \mathrm{C}$ terjadi penutupan permukaan seperti terlihat pada Gambar 10 berikut, dimana senyawa boride mulai memasuki substrat walaupun sedikit. Pada temperatur ini senyawa boron belum memiliki cukup energi untuk aktifasi Fe-B.

\section{Hasil Uji Mikro Vickers Spesimen Boriding $850^{\circ} \mathrm{C}$}

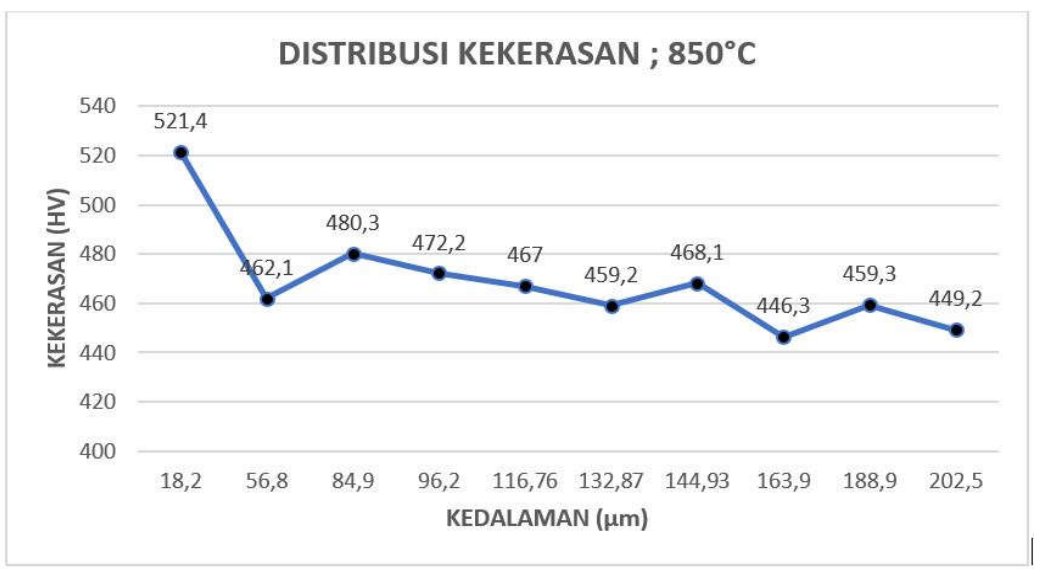

Gambar 12. Grafik Distribusi Kekerasan Spesimen $850^{\circ} \mathrm{C}$

Pada hasil pengujian distribusi kekerasan dengan beban 50 gram didapatkan data kekerasan permukaan luar spesimen sebesar 521,4 HV (lihat Gambar 11). Kekerasan dalam spesimen memiliki nilai yang cukup konstan dengan rata-rata 462,63 HV.

Sedangkan pada hasil pengujian mikro vickers (2) nilai HV yang didapatkan paling besar berada pada titik ke 3, yaitu 452,6 HV dan memiliki rata-rata HV sebesar 436,48 (lihat Tabel 6). Hasil pengukuran pada permukaan awal terdapat perbedaan yang cukup signifikan. Hal ini disebabkan oleh perbedaan bidang penekanan saat indentor menyentuh permukaan, sehingga pada saat metode pengukuran kekerasan permukaan, indentor telah menyentuh bagian dalam material yang relatif lebih lunak dibandingkan dengan kekerasan pada lapisan. Pada saat metode pengukuran cross-section atau distribusi kekerasan indentor menyentuh bagian luar lapisan dengan kedalaman 18,2 $\mu \mathrm{m}$ (sesuai Gambar 11). Maka dari itu nilai kekerasan yang didapatkan pun lebih tinggi. 
Tabel 6. Data Uji Kekerasan Permukaan Spesimen $850^{\circ} \mathrm{C}$

\begin{tabular}{cccc}
\hline No. & D1 $(\mu \mathrm{m})$ & D2 $(\mu \mathrm{m})$ & HV \\
\hline 1 & 27,11 & 34,02 & 425,7 \\
\hline 2 & 26,79 & 30,92 & 429,2 \\
\hline 3 & 32,12 & 27,94 & 452,6 \\
\hline 4 & 28,44 & 26,01 & 443,8 \\
\hline 5 & 27,78 & 27,87 & 431,1 \\
\hline & RATA - RATA & 436,48 \\
\hline
\end{tabular}

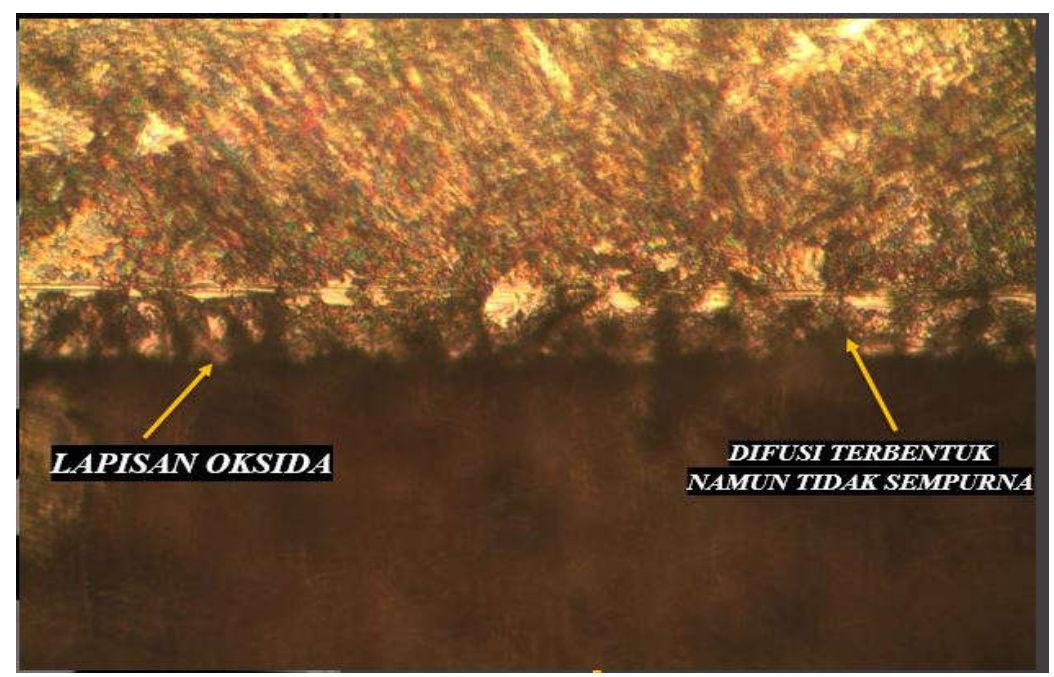

Gambar 13. Hasil Mikrostruktur Spesimen $850^{\circ} \mathrm{C}$

Hasil boronisasi pada temperatur $850^{\circ} \mathrm{C}$, lapisan boron sudah mulai terbentuk walaupun lapisan yang terbentuk tidak optimal. Namun pada temperatur ini difusi antara Fe dengan B sudah mulai terbentuk menjadi FeB. Hal ini dikarenakan waktu yang dilakukan pada percobaan ini adalah 1 jam, sehingga kedalaman difusi boron yag terjadi ke dalam material DIN 34CrNiMo6 tidak terlalu signifikan (lihat Gambar 12).

Hasil Uji Mikro Vickers Spesimen Boriding $950^{\circ} \mathrm{C}$

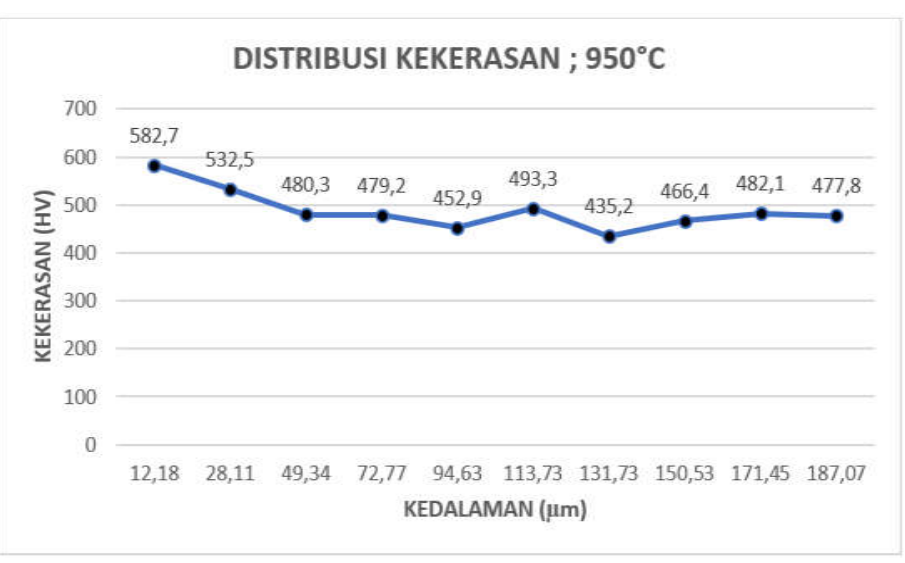

Gambar 14. Grafik Distribusi Kekerasan Spesimen $950^{\circ} \mathrm{C}$ 
Pada hasil pengujian Mikro Vickers (1) 50 gram didapatkan data kekerasan permukaan luar spesimen sebesar 582,7 HV (lihat Gambar 13). Kekerasan dalam spesimen memiliki nilai yang cukup konstan dengan rata-rata 542,48 HV.

Tabel 7. Data Uji Kekerasan Permukaan Spesimen $950^{\circ} \mathrm{C}$

\begin{tabular}{cccc}
\hline \multicolumn{4}{c}{ Spesimen $950^{\circ} \mathrm{C}$} \\
\hline No. & D1 $(\mu \mathrm{m})$ & D2 $(\mu \mathrm{m})$ & $\mathrm{HV}$ \\
\hline 1 & 26,89 & 30,64 & 482,9 \\
\hline 2 & 26,16 & 30,58 & 463,2 \\
\hline 3 & 27,18 & 29,39 & 472,5 \\
\hline 4 & 27,71 & 30,35 & 485,8 \\
\hline 5 & 27,04 & 27,04 & 477,2 \\
\hline & RATA - RATA & 476,32 \\
\hline
\end{tabular}

Pada hasil pengujian mikro vickers (2) nilai HV yang didapatkan paling besar berada pada titik ke 4, yaitu 485,8 HV dan memiliki rata-rata HV sebesar 476,32 (lihat Tabel 7).
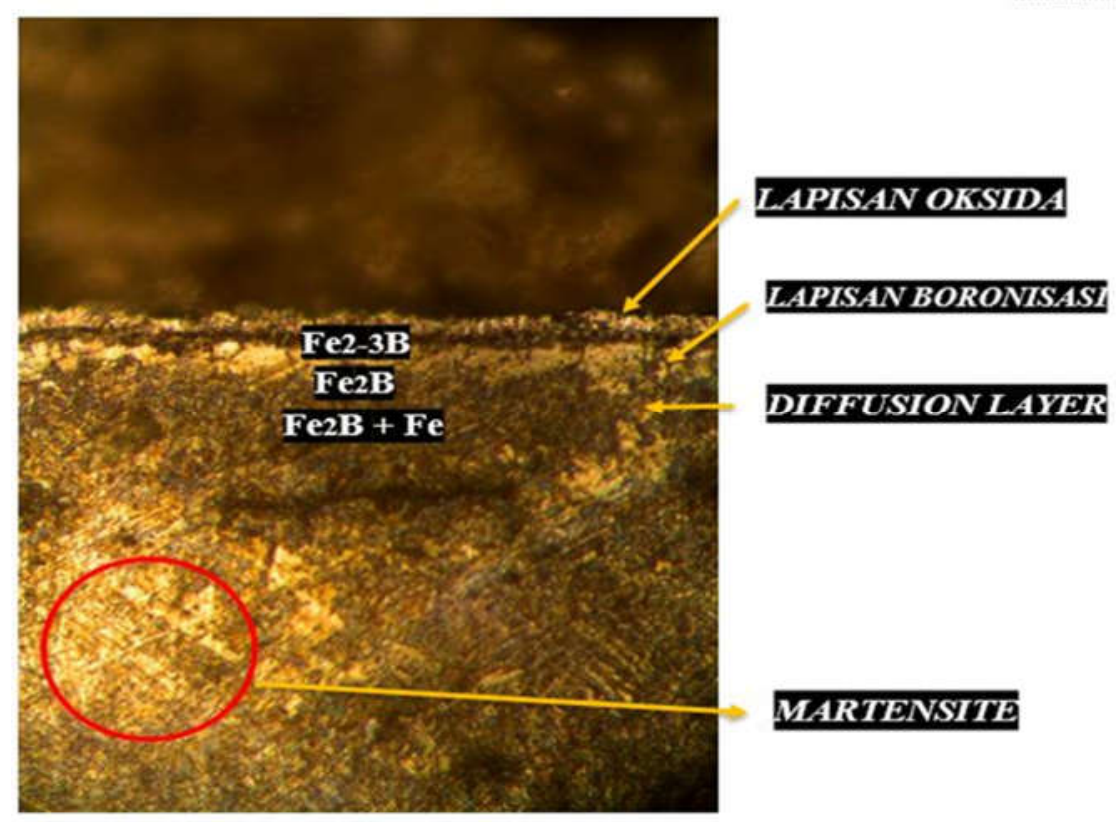

DIFFUSION LAYER

Gambar 15. Hasil Mikrostruktur Spesimen $950^{\circ} \mathrm{C}$

Pada temperatur $950^{\circ} \mathrm{C}$ terbentuk sebuah lapisan boron yang mengalami peningkatan, terlihat bahwa lapisan difusi Fe-B sudah terbentuk dengan adanya garis hitam di sepanjang batas antara benda kerja dengan mounting (lihat Gambar 14). Dengan demikian maka temperatur ini mampu untuk mengaktifkan energi boronisasi yang diperlukan pada proses boriding. Fe2-3B membentuk sebuah lapisan boronisasi, dimana Fe2B + Fe juga terbentuk sebagai lapisan difusi.

Struktur awal atau as-cast spesimen $950^{\circ} \mathrm{C}$ ini sudah memiliki struktur martensite, dengan morphologi struktur yang tajam pada bagian ujungnya. Setelah melalui proses boriding pada temperatur $950^{\circ} \mathrm{C}$ perubahan terjadi pada morfologi struktur menjadi struktur yang tumpul 
pada bagian ujungnya, martensite yang terbentuk merupakan lath martensite dimana struktur tersebut terbentuk pada material yang memiliki kadar karbon $<0.6 \%$ [2].

Hasil pengujian pada berbagai spesimen percobaan pada Gambar 14 dan 15 menunjukkan bahwa kekerasan dan kekerasan permukaan paling tinggi didapatkan pada spesimen $950^{\circ} \mathrm{C}$. Hal ini sejalan dengan hasil penelitian lain yang menyatakan proses boronizing dapat aktif pada temperatur $700-1000^{\circ} \mathrm{C}$ untuk kontak dengan media boron selama 1-12 jam [3]. Temuan penelitian ini juga sejalan dengan temuan fakta bahwa temperatur berkorelasi langsung dengan energi aktifasi boronisasi [11].

\section{SIMPULAN DAN SARAN}

\section{Simpulan}

Berdasarkan serangkaian hasil yang didapat dari hasil penelitian dapat disimpulkan bahwa temperatur pada proses boriding terhadap material DIN 34CrNiMo6 terbukti dapat mempengaruhi kekerasan permukaan material. Proses difusi FeB mulai terbentuk pada temperatur $850^{\circ} \mathrm{C}$ dan $950^{\circ} \mathrm{C}$. Temperatur optimal untuk proses boriding adalah pada temperatur $950^{\circ} \mathrm{C}$, karena proses difusi boron terhadap material terjadi dengan baik.

\section{DAFTAR RUJUKAN}

[1] Bringas, J. E. (2002). Handbook of comparative world steel standards. ASTM.

[2] Callister Jr. W.D. (2007). Materials Science and Engineering An Introduction, Seventh Edition.

[3] Joshi, A.A. and S.S. Hosmani. (2014). Pack-Boronizing of AISI 4140 Steel : Boronizing Mechanism and the Role of Container Design, Material and Manufacturing Process, vol. 29 pp 1062-1073.

[4] Krauss, George. (1997). Principle of Heat Treatment. Amerika. American Society for Metals.

[5] Metallurgical Articles, http://surface-heat.com/boronizing, diakses 12 Agustus 2019.

[6] Sandi, Putra. (2004). Powder Nitriding pada Baja Karbon Rendah dengan Menggunakan Urea. Skripsi Program Sarjana Teknik Material ITB Bandung: tidak diterbitkan.

[7] Scheneider, M.J. and M.S. Chatterjee. (2013). "Introduction to Surface Hardening of Steels", ASM International, vol. 4A.

[8] Scott, Benjamin. (2015). Abrasion Resistance of Concrete - Design, Construction and Case Study [Online], Vol 6 (3), 13 halaman. Tersedia : https://www.researchgate.net/ publication/281594259_Abrasion_Resistance_of_Concrete__Design_Construction_an d_Case_Study [16 Mei 2019].

[9] Setiawan A.B, \& W. Purwadi (2009). Pengaruh Temperatur Dan Waktu Proses Nitridasi Terhadap Kekerasan Permukaan FCD 700 Dengan Media Nitridasi Urea. Seminar Nasional Kluster Riset Teknik Mesin.

[10] Sugondo. (2005). "Aplikasi Teknologi Nano pada Pelapisan Paduan Baja Corten dengan Boron Karbida", 6th National Seminar on Microscopy and Microanalysis, Bogor

[11] Sugondo, R. Langenati, Widjaksana \& B.A. Pudjanto. (2006). "Pelapisan Baja Tipe ST37 Dengan Nano Powder Pack Boron Karbida", Jurnal Teknik Bahan Nuklir, vol 2 no.2 pp, 56-115, Juni-2006.

[12] Suratman, R. (1994). Panduan Proses Perlakuan Panas. Bandung : Lembaga Penelitian Institut Teknologi Bandung. 